\title{
Canção popular e música dionisíaca em Nietzsche
}

\begin{abstract}
Márcio José Silveira Lima*
Resumo: O artigo pretende analisar a relação entre canção popular e música dionisíaca, partindo das considerações metafísicas e musicológicas de Nietzsche em $\boldsymbol{O}$ nascimento $d a$ tragédia. Trata-se de apresentar os argumentos de Nietzsche no que tange à importância da canção popular no desenvolvimento das artes gregas que culminariam na tragédia. Mostrando como a união entre som e palavra exerce um papel decisivo nesse desenvolvimento, pretende-se expor as teorias nietzschianas sobre o tema em seus primeiros escritos, para, a seguir, defender que a autocrítica tardia do filósofo nos permite ampliar suas considerações musicais e assim pensar o contexto da música no século XX.
\end{abstract}

Palavras-chave: canção popular - canção folclórica - música dionisíaco - arte

\section{A canção popular grega.}

Dentre os muitos aspectos originais da estética do jovem Nietzsche está a forma como ele associa a música com o impulso dionisíaco, bem como os posicionamentos que defende a partir desse vínculo, tanto no âmbito metafísico, quanto na esfera da musicologia. Ou, ainda, podemos citar o lugar que ocupa esses aspectos no debate musical do Século XIX. Se um dos muitos elementos do dionisíaco se relaciona com a metafísica da vontade de Schopenhauer, há também a conexão desse viés metafísico que traduz o em si do mundo com as análises musicais que Nietzsche fará, especialmente no que se relaciona à união entre música e palavra, ou, também, na

\footnotetext{
* Professor da Universidade Federal do Sul da Bahia, Brasil. Correio eletrônico: marsil@ufsb.edu.br.
} 
possibilidade de combinação entre, de um lado, o som, o não-figurado, e, de outro, o conceito, a imagem figurada, próprios do mundo apolíneo. No processo histórico-artístico que fez nascer a tragédia grega, a canção popular [Volkslied] teria um papel decisivo, pois a música, como arte intrinsecamente dionisíaca, passa a ser unida a palavras, imagens e conceitos. Essa união, que teve vez na canção popular, e daí sendo introduzida na poesia lírica, por ser uma junção entre arte dionisíaca e apolínea, traria em si as condições para o nascimento da tragédia grega.

Essa miscelânea de perspectivas que se harmonizam na estética de juventude de Nietzsche, aquela de seus textos iniciais e que têm em $\mathrm{O}$ nascimento da tragédia sua expressão mais bem acabada, parece deixar seus intérpretes sempre em dificuldades quando se tenta privilegiar um tipo de abordagem em detrimento de outra, uma vez que o filósofo pensou nessas esferas unidas. Assim, o tipo de procedimento do intérprete corre sempre o risco de retirar da obra aquilo que nela é alicerce e sustentáculo. Talvez um bom exemplo disso seja a forma como a música é apresentada no segundo parágrafo de $\mathrm{O}$ nascimento da tragédia. Nas considerações inicias que faz sobre a tensão, no mundo grego, entre a visão dionisíaca e a apolínea, após introduzir os primeiros testemunhos de como houve uma junção entre as duas correntes artísticas, isto é, pela penetração de festas em homenagem a Dioniso, com seus cantos e danças, Nietzsche escreve:

O cântico e a linguagem mímica desses entusiastas de sentimentos duplos foram para o mundo grego-homérico algo novo e inaudito: a música dionisíaca, em particular, excitava nele espantos e pavores. Se a música, segundo parece, já era conhecida como uma arte apolínea, ela o era apenas, a rigor, tão só como ondulações do ritmo, cuja força figurativa foi desenvolvida até converter-se em exposição de estados apolíneos. A música de Apolo era arquitetura dórica em sons, mas só em sons insinuados, como os que são próprios da cítara. Mantinha-se cuidadosamente à distância, como não apolíneo, justo o elemento que 
constitui o caráter da música dionisíaca e, portanto, da música como tal: a violência estremecedora do som, a torrente unitária da melodia e o mundo completamente incomparável da harmonia. No ditirambo dionisíaco o homem é estimulado à máxima intensificação de todas as suas capacidades simbólicas (GT/NT 2, KSA 1.30).

De acordo com os processos de fusões metodológicas tão comuns em $\mathrm{O}$ nascimento da tragédia, podemos destacar nessa passagem pelo menos três níveis de abordagens: metafísica, histórica e musicológica. A tese metafísica se relaciona com a utilização dos conceitos de vontade e representação, vindos da filosofia de Schopenhauer. Frente a uma tradição que interpretou a cultura grega pelos seus atributos de beleza e medida, e identificou-os com a simbologia de Apolo, Nietzsche sustenta que por trás dessa aparência apolínea residia o fundo caótico próprio da sabedoria dionisíaca. Retomando a analogia de Schopenhauer para mostrar que o mundo como representação cobre o mundo como vontade, à maneira do Véu que cobre a face de Maya, Nietzsche afirma que assim é em relação à consciência apolínea, que apenas recobre os abismos dionisíacos. Nos parágrafos posteriores de $\mathrm{O}$ nascimento da tragédia, ao analisar a relação entre música e palavra, não raro os pressupostos metafísicos de Schopenhauer também darão o tom das teorias nietzschianas.

Já a perspectiva histórica defende que, como forma sonora, a música dionisíaca é posterior à apolínea entre os gregos. Somente depois de terem desenvolvida a música com a rítmica apolínea é que os gregos teriam conhecido a música dionisíaca. Todavia, se nos ativermos à tese metafísica, Nietzsche parece cair em contradição. Não só em relação aos argumentos anteriores sobre o encobrimento da aparência apolínea sobre as profundezas dionisíacas, mas também em importantes passagens posteriores, Nietzsche concebe que todo o mundo aparente, aí incluindo as artes, surge como expressão de uma vontade, de uma essência, que é própria do impulso dionisíaco. Assim, quando analisa as condições de surgimento 
da tragédia, o filósofo postula a introdução da canção popular na lírica como o primeiro momento de união entre uma arte apolínea e outra dionisíaca, e que esse acontecimento representa, nas artes, uma forma de relação entre os impulsos naturais dos dois deuses, ou seja, todo o mundo conceitual e figurativo, próprios de Apolo, não passa de uma transformação do ímpeto dionisíaco, o qual se manifesta primeiro em forma de música.

Nesse sentido, e aqui voltamos sub-repticiamente à tese metafísica, o dionisíaco precede o apolíneo, tanto da perspectiva fisiológica, quanto da artística. Por que então os gregos, o povo mais sensível às artes, como afirma o próprio Nietzsche, conheceu primeiro a canção apolínea e só depois a dionisíaca? Não deveria ser o contrário? Se toda arte figurativa nasce de um impulso não figurado, a música dionisíaca não deveria anteceder historicamente a apolínea? Será que Nietzsche considera que da perspectiva metafísica e da natureza o dionisíaco precede o apolíneo, mas da perspectiva histórico-artística ocorre o contrário? ${ }^{1}$ Também é possível considerar que essa seja uma das razões pelas quais o próprio Nietzsche, no "Ensaio de autocrítica", condenou seu primeiro livro porque se eximiu de dar demonstrações e porque nele faltava vontade de limpeza lógica (Cf. GT/NT, Ensaio de autocrítica, 3, KSA 1.14)2.

\footnotetext{
1 Nos comentários que faz a $O$ nascimento da tragédia em Ecce homo, Nietzsche sente um cheiro indecorosamente hegeliano em seu primeiro livro, e destaca justamente a oposição entre o apolíneo e o dionisíaco e sua transposição para o metafísico, além de considerar a própria história como o desenvolvimento dessa oposição $(\boldsymbol{E H} / \boldsymbol{E H}, \mathrm{O}$ nascimento da tragédia, 1, KSA 6.309). Poderíamos, ainda, compreender essa relação histórico-metafísica no que tange à música nos moldes de Hegel, para quem, da perspectiva do belo na arte, é preciso diferenciar, nas obras de artes, aquilo que é segundo sua natureza daquilo que é segundo sua história efetiva. Uma obra pode ser simples segundo sua natureza, embora seu início possa não ter necessariamente a marca dessa simplicidade (Hegel, 2014, p. 17). Nesse sentido, da perspectiva metafísica e artística, a música dionisíaca pode ser anterior à apolínea, embora do ponto de vista da história efetiva não o seja.

2 Silk \& Stern (1983, p. 242) apontam para uma incoerência na tese do parágrafo 2 de $O$ nascimento da tragédia e sobre a música apolínea ali mencionada, na medida em que os princípios teóricos defendidos concebem a arte sonora como sendo apenas dionisíaca. Nesse aspecto, Nietzsche se exime de fazer qualquer discussão sobre esse ponto.
} 
Sobre o terceiro ponto, relativo à musicologia, Nietzsche invoca o três elementos constitutivos da música moderna, o ritmo, a melodia e a harmonia, para demarcar a diferença entre os sons ditos apolíneos e os dionisíacos. Há toda uma discussão musicológica sobre a existência de harmonia na música grega, e a tendência é a de negar essa possibilidade; por isso, podemos considerar que essa é mais uma das muitas teses polêmicas que o filósofo defende em $\mathrm{O}$ nascimento da tragédia3. Tudo somado, a passagem que acima destacamos do segundo parágrafo do livro nos deixa com pelo menos três questões para entender a questão da música. Indissociáveis estão as teses metafísicas e históricas sobre o problema da temporalidade, às quais se junta a afirmação da existência da harmonia já na música grega.

Em relação aos dois primeiros pontos, devemos considerar que Nietzsche situa sua primeira exposição sobre o surgimento da música dionisíaca entre os gregos num momento histórico posterior, isto é, no mundo homérico, aquele que é precisamente o auge da visão apolínea de mundo. Portanto, continua valendo a tese metafísica de que sob o aparente edifício da cultura apolínea estava o alicerce dionisíaco. Embora em nenhum momento Nietzsche deixe claro ou argumente nessa direção, é lícito considerar que houve uma música de caráter dionisíaco anterior àquela que ele descreve, aí já se valendo da tradição de estudos sobre o ditirambo, por exemplo. De certo modo, é possível afirmar que Nietzsche esteja pensando as condições artístico-musicais gregas numa chave de leitura que as compare com as discussões de sua época. Questionando a imagem mais corrente sobre os gregos, o filósofo concebe

3 Christophe Corbier (2004) apresenta um abrangente panorama dessa discussão em torno da música e da harmonia e a diferença entre os gregos e modernos, explicando por que Nietzsche tinha razões para considerar a existência da harmonia já entre os gregos. Citando vários fragmentos do início dos anos 1870 nos quais Nietzsche argumenta em favor de sua tese, Corbier afirma que uma das formas como o filósofo via a existência da harmonia na música grega era por meio de uma heterofonia ligando o coro ao emprego de um acompanhamento de instrumentos de sopro (p. 79). 
que aquilo que era considerado bárbaro já estava entre os gregos, fazia parte de seu alicerce.

Com efeito, a estranheza que Nietzsche descreve dos homens gregos homéricos diante dos entusiastas dionisíacos, com seu cântico e sua mímica, reside na negação daquilo que esses mesmos homens julgavam ser a essência do dionisíaco, isto é, seu aspecto grosseiro, sua origem bárbara e selvagem. Uma imagem que os gregos criaram para si mesmos, na tentativa de afastar-se da influência dos bárbaros, e que teria sido legada aos pósteros. Justamente por isso, da perspectiva histórica, não teríamos mais elementos para conhecer de forma satisfatória os traços dessa cultura, e o aspecto mais evidente desses traços só seriam conhecidos numa outra etapa, quando se fez uma nova irrupção do dionisíaco, dessa vez vindo do estrangeiro.

"Titânico" e "bárbaro" pareciam ao grego apolíneo também o efeito provocado pelo dionisíaco: sem poder dissimular-se, apesar disso, que ele próprio aparentava-se intimamente com aqueles Titãs e heróis abatidos. Devia, inclusive, sentir algo mais: sua existência inteira, com toda sua beleza e moderação, repousava sobre um velado substrato de sofrimento e de conhecimento, que lhe era de novo revelado por meio do dionisíaco. E eis que Apolo não podia viver sem Dioniso! O "titânico" e o "bárbaro" eram, em última instância, uma necessidade exatamente igual ao apolíneo! (GT/NT 4, KSA 1.38)

Na contraposição entre, de um lado, os gregos e, de outro, os selvagens e bárbaros, Nietzsche parece querer destacar a importância desses últimos para um aspecto fundamental da própria cultura grega: sua sensibilidade para o lado terrível e problemático da existência. Como afirma em comentários posteriores sobre $\mathrm{O}$ nascimento da tragédia, uma das principais virtudes de seu primeiro livro foi o de ter trazido à tona um aspecto importante da cultura grega que tanto os helenos quanto à tradição posterior tentou negar (GD/CI, O que devo aos antigos, KSA 6.154). Nesse aspecto, o que 
Nietzsche faz é uma apropriação dessa tradição interpretativa para dar-lhe um novo significado. Talvez menos do que atribuir uma influência externa para a cultura grega, trata-se de mostrar que o contato com o bárbaro dionisíaco fez vir à luz aquilo que estava escondido, ou que os próprios gregos, no auge de sua cultura apolínea, quiseram negar.

E agora imaginemos como nesse mundo construído sobre a aparência e a moderação, e artificialmente represado, irrompeu o som extático da festa dionisíaca com melodias mágicas cada vez mais sedutoras, como nelas a desmesura [Uebermaass] inteira da natureza se dava a conhecer em prazer, dor e conhecimento, até chegar ao grito estridente; imaginemos o que podia significar, comparado com esse demoníaco canto popular [Volksgesange], o salmodiante artista de Apolo, com o som espectral da harpa! As musas das artes da "aparência" empalideciam diante de uma arte que em sua embriaguez falava a verdade [...] (GT/NT 4, KSA 1.38).

\section{O fundo sonoro da canção popular}

É possível considerar que os mesmos elementos históricos e culturais até aqui expostos estão no fundo da análise musicológica de Nietzsche quando ele atribui já à música grega os elementos da música moderna. De fato, ele parece suprimir séculos de diferença histórica e leva em consideração as duas músicas como se estivessem no mesmo plano, ou seja, Nietzsche considera que melodia, ritmo e harmonia, por ser universais, está virtualmente presente em qualquer música4. Além disso, e aqui está o mais importante, na

4 Silk \& Stern (1983, p. 244) consideram que Nietzsche, quando trata da música em $O$ nascimento da tragédia, independente de que época esteja analisando, tem por modelo a tradição tonal da música do Ocidente; quando tenta mostrar a singularidade da música grega, ele falha em seu objetivo. Corbier (2004, p. 95), por sua vez, mostra justamente a aporia a que essa visão panorâmica conduz, uma vez que Nietzsche depende dela para defender a harmonia na música grega. No entanto, o filósofo também condena a ópera moderna como não tendo filiação com a sonoridade antiga. Nesse caso, haveria uma singularidade harmônica da música grega, diferente da música moderna. E o filósofo arrola argumentos a favor tanto de uma tese quanto de outra. 
época de $\mathrm{O}$ nascimento da tragédia, seu interesse pela arte sonora grega é indissociável do lugar que o filósofo deseja ocupar no debate cultural de sua época. Nesse sentido, aquele embate cultural entre gregos e bárbaros será redimensionado para se pensar a questão da música e da cultura no final do século XIX, quando o tema dos nacionalismos se mostrava com toda a força5.

Por isso, se a canção popular teve um lugar de destaque no desenvolvimento cultural grego e foi decisiva para a irrupção da tragédia, é possível pensar que, para Nietzsche, essa mesma canção teria ainda um papel a desempenhar. Com isso, é preciso afirmar que as considerações de Nietzsche sobre a música e o papel dessa arte como fonte de renovação da cultura não estava associada apenas ao nome de Wagner. Se o filósofo mais tarde vai tentar se afastar dessa sua imagem tão ligada ao compositor que ele próprio construiu, devemos, contudo, pensar que já na época da escrita de $\mathrm{O}$ nascimento da tragédia o filósofo desenvolveu reflexões importantes no que tange ao lugar da música e de suas possibilidades filosóficas e culturais, as quais, a nosso ver, não se ligam ao nome de Wagner. Adorno percebe isso com muita clareza quando afirma: "Nietzsche, que tinha mais faro para aspectos sociomusicais que qualquer outro, elevou-os ao ápice na medida em que, sob a égide da imagem ideal da Antiguidade, uniu a crítica do conteúdo e a crítica estética de maneira imediata" (Adorno, 2009, p.152). Com Adorno, portanto, podemos considerar que Nietzsche, no limite, pensa seu tempo e o universo da música de sua época por meio dessa "imagem ideal da antiguidade".

Nesse aspecto, tomando partido pela própria autocrítica que Nietzsche fará a seu primeiro livro, podemos retirar das análises históricas e musicológicas da música seus elementos metafísicos,

5 No "Ensaio de autocrítica" Nietzsche começa a reflexão sobre seu primeiro livro precisamente invocando as condições históricas em que foi escrito, isto é, no meio da guerra Franco-Prussiana e suas consequências por toda Europa, lamentando, depois, a filiação romântica do livro (GT/NT, Ensaio de autocrítica, 1, KSA 1.11). 
de sorte a pôr em evidência o componente artístico da obra de arte musical e sua possível função de ligar as culturas antiga e moderna. Um ponto central dessa autocrítica e da consequente ampliação do campo de reflexão musical é a forma mesma como Nietzsche vai reavaliar o romantismo. De fato, não resta dúvida de que o romantismo foi um movimento fundamental para o século XIX, pois deixou marcas na filosofia, literatura e na música, nas quais o movimento romântico está associado às tendências de afirmação nacional. Se Nietzsche quis buscar na canção popular um dos elementos mais importantes da cultura grega, uma vez que era a expressão do dionisíaco, é preciso reconhecer então a dívida com traços similares da posição dos românticos, para quem canção folclórica e identidade de um povo mantinham vínculos. E havia nisso um tanto de busca por renovação da linguagem musical.

Na Alemanha, por exemplo, considera-se o precursor dessa nova visão musical o compositor Carl Maria Friedrich Ernst Freiherr von Weber. Em Ópera e drama, na reconstituição que faz da história da ópera, Wagner reconhece o lugar de destaque de seu antecessor. Se até então, na ótica do compositor de Parsifal, a ópera tinha sido uma tentativa equivocada de restauração da tragédia grega, isso se devia a uma confusão entre os meios e os fins, pois a música estava desvirtuada de sua verdadeira finalidade, que era a de servir ao drama, à ação, tornando-se um fim em si mesma. Weber teria indo numa direção oposta, pois desde Der Freischütz (O Franco-Atirador) buscou basear suas óperas numa melodia popular que encarnava o genuíno espírito alemão, e nas quais o povo era o protagonista (Wagner, 1852, pp. 35/36).

Nietzsche toma parte nesse debate, aprofundando essa mesma perspectiva, da qual podemos destacar duas estratégias: primeiro, desenvolver a ideia de que a música grega era a expressão de uma essência dionisíaca, e que a canção popular, como arte sonora do povo, desempenhou um papel decisivo para fazer nascer a tragédia; segundo, mostrar como a ópera, em sua tentativa de 
restaurar a tragédia, teria malogrado porque, em vez de buscar no espírito popular as condições para isso, amparou-se em premissas intelectuais e teóricas, justamente as responsáveis por dar fim à tragédia na antiguidade, como Nietzsche afirma ao acusar Sócrates e Eurípedes. No primeiro caso, é o exemplo do poeta Arquíloco que Nietzsche toma como objeto de análise e de demonstração de sua tese, numa reformulação da visão sobre o caráter objetivo e subjetivo da arte. Em linhas gerais, esse redimensionamento se faz necessário porque a tradição estética atribui ao artista subjetivo um vínculo à sua subjetividade, sendo o poeta lírico a mais bem acabada expressão desse processo. Para Nietzsche, ao contrário, o poeta lírico não está, na verdade, preso à sua subjetividade. Pressupondo a caracterização metafísica do dionisíaco e do apolíneo, o poeta lírico não tem sua filiação mais acentuada com os preceitos da individuação apolínea, mas com o fundo caótico que revela a essência das coisas. Portanto, toda a imagética e acabamento conceitual que expressam a poesia lírica têm como princípio metafísico a música dionisíaca.

No processo dionisíaco, o artista já renunciou à sua subjetividade: a imagem que sua unidade com o coração do mundo lhe mostra agora é um cena onírica, que torna sensíveis aquela contradição e aquela dor primordiais junto com o prazer primordial próprio da aparência. O "eu" do lírico soa, portanto, a partir do abismo do ser: sua "subjetividade", no sentido dos estetas modernos, é pura imaginação [Einbildung]. Quando Arquíloco, o primeiro lírico dos gregos, proclama seu furioso amor e, ao mesmo tempo, o seu desprezo pelas filhas de Licambes, não é sua paixão que dança diante de nós em torvelinho orgiástico: vemos Dioniso e as Mênades, vemos o embriagado entusiasta Arquíloco deitado a dormir tal como Eurípides nos descreve o dormir em As bacantes, em elevado prado na montanha, ao sol do meio-dia -: e agora Apolo se aproxima e o toca com o seu laurel. O encantamento dionisíaco-musical do dormente lança agora a seu redor, por assim dizer, centelhas de imagens, poesias líricas, que, em seu desdobramento supremo, se chamam tragédias e ditirambos dramáticos (GT/NT 5, KSA 1.42). 
Como revela a passagem, se o poeta lírico é um artista que produz em essência uma arte dionisíaca, Arquíloco expressou duplamente aquelas que seriam as condições para o nascimento da tragédia, pois não apenas seus poemas revelariam uma ascendência musical, como ele também foi responsável pela introdução da canção popular na poesia lírica. Seria um segundo momento histórico decisivo nas etapas que Nietzsche julga decisivos para a constituição da tragédia. A primeira, como vimos, foi naquele instante em que a música dionisíaca adentrou a Grécia, que, em seu momento homérico e apolíneo, conheceu uma nova modalidade musical. Nessa segunda etapa, por um processo similar, a pulsão artística dionisíaca invade o terreno de seu opositor, quando a canção extrapola sua condição metafísica de dar à luz as imagens e conceitos, e ela mesma se une num novo formato, o da poesia lírica, união germinal entre música e palavra que mais tarde culminará no nascimento da tragédia.

Nos escritos não-publicados da época de $O$ nascimento $d a$ tragédia (Nachlass/FP 12 [1], 1871, KSA 7.359), Nietzsche faz considerações mais agudas sobre a relação entre música e palavra que explicam melhor o lugar do poeta lírico e de sua relação com a música, tornando mais explícito por que Arquíloco merece um lugar de destaque no desenvolvimento artístico que levaria à tragédia. Fazendo uma analogia com a distinção schopenhaueriana entre vontade e representação, Nietzsche afirma estar o gestual para o prazer e a dor assim como a linguagem está para a música. Todos os gestos corporais são manifestações empíricas de uma vontade universal que simboliza o prazer e a dor. Da mesma forma, as linguagens particulares são representações da universalidade sonora. Ainda na senda de Schopenhauer, o que ocorre em relação à música é que o intelecto se sente impelido a construir esquemas, por meio de imagens e conceitos, que possam traduzir o conteúdo sonoro. Nietzsche considera, inclusive, que esse "esquematismo" pode explicar o surgimento e a diversidade de línguas. O filósofo 
afirma, além disso, que a relação entre sons e gestos é a base para o desenvolvimento da própria linguagem.

Julgamos poder incluir todo o âmbito do consonantismo e do vocalismo no simbolismo dos gestos [Geberdensimbolik] - as consoantes e as vogais, sem o som fundamental que é, acima de tudo, necessário, não são mais que posições do órgão da linguagem, em suma, gestos -; quando pensamos na palavra que brota dos lábios do homem, se produz então pela primeira vez a raiz da palavra, o fundamento daquele simbolismo dos gestos, ou seja, of fundo sonoro [Tonuntergrund ] [...](Nachlass/FP 12 [1], 1871, KSA 7.359).

Essa relação entre o fundo sonoro e a linguagem nos permite entender por que a música de cada povo começa sempre unida à lírica, muito antes de ser possível falar em música absoluta. Mas a música não apenas levaria inevitavelmente à lírica como também à canção popular. Enquanto esta é signo de uma coletividade, de um povo, permanece mais universal e original, enquanto aquela, por meio do filtro da imagem e do conceito, vai se distanciando desse fundo comum sonoro. Ora, à medida que vai sendo tomada pela imagética e pela formação conceitual, a poesia lírica parece adentrar o reino do impulso apolíneo. Como na modernidade a poesia lírica já não traz mais junto de si sua parte musical, Nietzsche vai contrapor-se às ideias estéticas da época moderna que consideram o poeta lírico um artista subjetivo e preso às malhas do eu. Porque o lírico está preso às suas origens musicais, ele não é um poeta subjetivo, uma vez que sua poesia, mesmo sendo conceitual e imagética, permanece ligada àquele fundo musical. Assim, quando Arquíloco introduz a canção popular na literatura, a poesia lírica que decorre dessa união entre som e palavra soará estranha ao mundo da aparência épica. Porque a melodia lança à sua volta centelhas de imagens, e sua policromia revela uma força selvagem, os solenes rapsodos dos épicos das festas apolíneas, tais como Terpandro, acabaram por condenar a poesia lírica, cuja forma estava marcada 
pela presença da canção popular, o que provocava o estranhamento naqueles ouvintes acostumados ao epos (Cf. GT/NT 6, KSA 1.48).

Essas reflexões sobre canção popular, cuja forma artística expressa os aspectos principais do impulso dionisíaco, isto é, seus elementos não figurados, bem como sua forma sonora que simboliza as forças naturais, permitirão a Nietzsche reprovar o projeto musical moderno sempre que este estabelecer outra relação entre música e palavra. E as bases teóricas com que a estética moderna reinterpretou e tentou dar vida àqueles princípios gregos serão criticadas por Nietzsche em pelo menos dois aspectos. Primeiro, como se interpretou a noção de homem natural, aquele integrante do coro que entoava ditirambos a Dioniso. Segundo, como se inverteu a relação entre música e os demais componentes com que ela se unia, como a palavra, os sentimentos e a ação.

Sobre o primeiro ponto, como Nietzsche afirma no parágrafo terceiro de $O$ nascimento da tragédia (GT/NT 3, KSA 1.34), sua concepção do homem dionisíaco grego nada tem a ver com a concepção moderna do homem primitivo, oriunda da filosofia de Rousseau. Aquela noção de que os homens, em seu estado natural, habitavam o coração da natureza e mantinham com ela uma relação harmoniosa é uma falácia. Em seu entender, o mito de Sileno é a melhor expressão de que os gregos nunca mantiveram essa relação idílica com a natureza; antes estavam diante dela com assombro, e toda sua visão de mundo, especialmente a artística, é uma manifestação de como inverteram o conselho de Sileno, pois tiveram de lutar com os aspectos terríveis das forças naturais; a arte grega é um testemunho dessa luta e de sua transfiguração. Diante disso, a ópera moderna, cuja relação entre música e palavra é a tentativa mais evidente da retomada da música antiga, ao partir de pressupostos teóricos equivocados sobre a natureza do homem primitivo, não pôde penetrar na essência da música que representava a melhor tradução das forças naturais dos homens antigos. $\mathrm{O}$ efeito mais visível desse erro foi a música, no fim das contas, servir às palavras 
e às imagens, pois a música é considerada como escrava, a palavra como senhor; a música é comparada ao corpo e a palavra do texto à alma (GT/NT 19, KSA 1.120). E com isso adentramos o segundo ponto da crítica de Nietzsche.

A estética musical moderna inflige uma inversão que, na metáfora do filósofo, obriga o filho a fazer nascer o pai (Nachlass/FP 12 [1], 1871, KSA 7.359). Tal é a situação de uma música que pretende fazer o componente sonoro acompanhar o sentimento, a imagem ou a ação. Na lírica antiga, quando o compositor compunha uma canção lírica, a excitação musical [musikerregung] era a responsável por dar forma a um texto que era a expressão simbólica de si mesma. O texto poético era condicionado completamente pela forma musical de onde havia nascido. Assim, o poema não surge como expressão da completa liberdade imaginativa do poeta; a música impõe a forma das palavras, das imagens e dos sentimentos. Como veremos adiante, é preciso notar que essa crítica à música moderna não é direcionada à totalidade da arte sonora, mas apenas à tendência que se encaixa nessa confusão entre som e palavra. Por isso, a crítica de Nietzsche visa à ópera e à tentativa de submeter a música a um programa baseado em imagens, sentimentos e ação, e àquele estilo que culminou no romantismo e na música programática.

Sobre essas duas tendências, Nietzsche julgava que a Alemanha as confrontava, ou pelo efeito das filosofias de Kant e Schopenhauer, que tinham posto fim ao otimismo teórico, ou pelo trabalho artístico de Wagner, o qual estava consumando a tradição da música alemã, e fazendo, enfim, renascer a tragédia grega. Nesse aspecto, Nietzsche considera que Tristão e Isolda recupera uma corrente da música moderna que não padecia dos equívocos que ele criticara, e por isso mesmo era o casulo de onde nasceria outra vez uma obra de arte em que a junção entre palavra e música continha a mesma potência da antiguidade grega. Embora essa afirmação sobre a obra wagneriana esteja clara, é preciso considerar mais de perto seu significado. Pois, apesar desse posicionamento de Nietzsche, são 
poucas as passagens de $O$ nascimento da tragédia em que ele tenta demonstrar sua tese. $\mathrm{E}$, mais ainda, nos escritos preparatórios não se encontra esse mesmo tom entusiástico.

Sabemos que no "Ensaio de autocrítica" Nietzsche nega essa dupla tradição alemã, tanto a filosófica, quanto a musical, afirmando que ela estragou o que tinha a dizer sobre os gregos. Além disso, sua obra posterior vai silenciar sobre muitos aspectos que estavam em seu primeiro livro. Seria natural, nesse contexto, que suas considerações, em seus textos iniciais, sobre a canção popular e o que nela escande, ou seja, os muitos elementos próprios do dionisíaco, sofressem com esse silêncio. Como acontece na vasta produção dos textos publicados e não-publicados do início dos anos 1870, Nietzsche assume posições ambíguas. Enquanto condena nos fragmentos póstumos a música romântica programática e por vezes a música de Wagner, em $O$ nascimento da tragédia elogia o compositor. Suas reflexões em torno da canção popular e sua ligação com a música de forma geral e a palavra vão oscilar no meio dessa miscelânea. Assim, nos escritos tardios, tende a associar Wagner ao movimento geral do romantismo em seus princípios estéticos e filosóficos. Por isso, no "Ensaio de autocrítica", Nietzsche tanto lamenta também o fato de seu primeiro livro ser romantismo de ponta a ponta, quanto se pergunta, no final do texto, onde ainda poderia ouvir novamente uma música dionisíaca. Além de condenar sua adesão inicial a Wagner e Schopenhauer, vemos aí também uma tentativa de desvincular sua caracterização do dionisíaco e sua concepção natural e musical do que significou o movimento romântico. Mas a que romantismo o filósofo se refere, mesmo tendo em vista o contexto de sua primeira obra? Aquele romantismo desenvolvido junto à escola de Rousseau, ou aquele outro da escola musical alemã? Talvez os dois, ou talvez nenhum.

Escrito contemporâneo ao "Ensaio de autocrítica", o parágrafo 370 de $A$ gaia ciência responde precisamente à pergunta: o que é romantismo? Texto labiríntico, com múltiplas perspectivas 
que se abrem diante do leitor, é possível entender que aquele romantismo inicial estava associado a Wagner e Schopenhauer, e tem a ver com o pessimismo $(F W / G C 370, \mathrm{KSA} 3.619)$. É bem verdade que Nietzsche acusa toda a música alemã de ser romântica, e nem a polarização entre Wagner e Brahms escaparia àquilo que revela a essência dos alemães no século XIX. Mas o que acontece com a canção popular, cujos pressupostos teóricos foram tão importantes para a estética inicial nietzschiana, especialmente por fazer germinar a tragédia grega? Ora, a importância dessa forma artística está ligada sobretudo às investigações de Nietzsche sobre a estética grega e sua importância para a tragédia. Quando considera a música de forma geral, assim como suas formações na época moderna, encontramos como pano de fundo esses princípios estéticos que culminaram na tragédia, embora a canção popular mesma não seja tomada como modelo. Ou seja, com raras exceções, a canção popular só é levada em consideração por Nietzsche nas análises da arte grega em seu primeiro livro.

Uma possível explicação para esse tratamento talvez seja o próprio lugar que a música popular ocupava à época em que Nietzsche escrevia, ou seja, no final do século XIX. Embora vá se tornar um modelo decisivo de uma forma muito particular para a estética musical posterior à produção intelectual do filósofo, na época em que estava intelectualmente ativo o tipo de relação que se estabelecia com a canção popular era sobretudo aquela praticada pela escola romântica.

\section{O contexto pós-romântico.}

A partir das obras do período tardio, embora as preocupações teóricas de Nietzsche em torno da música tenham diminuído, e as duas obras que ele publicou já no final de sua produção intelectual estejam ligadas diretamente a Wagner, é possível ampliar o alcance dessas preocupações tomando como motivo principal a 
pergunta pelo dionisíaco feita no "Ensaio de autocrítica", de 1886, bem como as críticas e autocríticas que o autor faz e que têm um vínculo estreito com a pergunta. Ao recolocar o problema da música dionisíaca, é possível entender essa nova aparição da temática como um ritornelo. Com efeito, nos temas e motivos que Nietzsche apresenta sobre a música estão as reflexões do ponto de vista das questões que a própria obra traz, como também da perspectiva de um possível diálogo que ela estabelece com a música para além das considerações internas de seu próprio pensamento. E esse último aspecto pode nos revelar um solo bem fecundo em se tratando da visão de Nietzsche sobre a música.

Assim, do ponto de vista atinente às questões que a própria obra retoma, a música dionisíaca pode ser primeiramente remetida ao contexto de rompimento com Wagner, Schopenhauer e o romantismo. Com isso, desvencilhada das teorias que teriam estragado o que o filósofo tinha a dizer sobre os gregos (GT/NT, "Ensaio de autocrítica", 6 KSA 1.19), essa nova forma dionisíaco-musical seria um último apelo de Nietzsche para que as formas sonoras gregas pudessem servir de modelo para a música, levando em consideração menos três aspectos: a união entre música e palavra, a proximidade da música com a canção popular e a força que expressa a coletividade de um povo que ainda não se afastou dos impulsos naturais. Além disso, ao retomar o dionisíaco pelo viés dos rompimentos, mas também sem perder de vista esses três aspectos, é possível ver "afinidades eletivas" entre as concepções de Nietzsche sobre e o contexto musical do pós-romantismo, sobretudo na utilização da linguagem da canção folclórica e popular por causa de sua força primitiva e natural, ainda não tocada pelo aparato teórico da música europeia ${ }^{6}$. Em $O$ caso Wagner, por exemplo, no elogio que faz à ópera Carmen, de Bizet, essa ligação entre canção

6 Em $O$ caso Wagner (WA/CW 1, KSA 6.13), Nietzsche afirma que, permanecendo popular, a música de Carmen é maliciosa, refinada e fatalista, e nisso se contrapõe à música poliposa de Wagner com sua melodia infinita. 
popular e natureza aparece de forma muito pontual ${ }^{7}$. A despeito disso, Nietzsche diz que aspectos centrais de Carmen, como leveza e refinamento de uma raça, se explica pelo que nela é ainda música popular. Aliás, o que há de popular nela, e que dá mostras de uma outra sensibilidade, é justamente o que a leva para longe tanto da música francesa quanto da alemã. "Sua alegria é africana; ela tem a fatalidade sobre si mesma, sua felicidade é curta, repentina, sem perdão. Invejo Bizet por isso, por haver tido a coragem para esta sensibilidade, que até agora não teve idioma na música cultivada na Europa" (WA/CW 2, KSA 6.15) ${ }^{8}$.

É possível que haja mais que sinceridade nessa confissão de Nietzsche acerca de sua suposta falta de coragem para aquilo que fizera Bizet. Ora, quando escreveu $O$ nascimento da tragédia, esse apelo para uma música que extrapolasse os limites tonais da arte sonora europeia estava associado ao entusiasmo pela obra de Wagner. Assim, Nietzsche julgava que o compositor alemão realizava essa tarefa por retomar aspectos da música grega, fazendo com isso ressurgir aquela torrente sonora da música dionisíaca. Num caso como no outro, isto é, no de Bizet e no de Wagner, permanece ainda como um problema filosófico-musical encontrar essa outra linguagem. A diferença, contudo, consiste na identificação dessa linguagem com o pathos dionisíaco, pois enquanto no início o nome de Wagner se associava à música dionisíaca, o de Bizet não. Quiçá, apesar de todos os elogios à ópera de Bizet, Nietzsche ainda não a considerasse a música de origem dionisíaca que ele próprio procurava, apesar de seu estrangeirismo e de trazer ainda alguma sonoridade da canção popular.

Cabe lembrar que a pergunta pela música dionisíaca, no

\footnotetext{
7 Nietzsche por um instante interpreta a ópera Carmen numa chave de leitura de sua concepção de retraduzir o homem de volta à natureza $(W A / C W 1$, KSA 6.13). Além disso, sua derradeira consideração sobre a música está marcada pela noção fisiológica tomada de empréstimo de Paul Bourget. A esse respeito, ver Éric Dufour (2001).

8 Tradução de Paulo César de Souza.
} 
"Ensaio de autocrítica", é anterior às afirmações que Nietzsche faz sobre a ópera de Bizet. Em o Caso Wagner, ele não faz nenhuma relação entre as duas coisas, isto é, o caráter estrangeiro e popular de Carmen com a música dionisíaca. Nesse sentido, Carmen é considerada uma música nova, com uma sonoridade estrangeira e popular, mas não seria ainda a música dionisíaca. Por isso, defendemos uma chave de leitura que leve em consideração a união entre canção popular e o pathos dionisíaco, como estava posta em $O$ nascimento da tragédia, todavia reformulando seu significado. Em outras palavras, é mais uma vez a canção popular que pode nos ajudar a responder a Nietzsche onde ainda se poderia ouvra uma música que não fosse romântica, mas dionisíaca.

Se os argumentos de Nietzsche sobre a música dionisíaca nos leva a considerar que a ópera Carmen contenha em estado germinal algo de uma nova sonoridade, as transformações por que passa a linguagem musical nos contexto pós-nietzschiano parecem conter muitos elementos que encontramos ao longo da obra do filósofo, especialmente no que tange à renovação da música tonal por meio da absorção da linguagem da canção folclórica e pela superação do romantismo, duas vertentes que aparecem unidas em suas reflexões tardias. Filósofos e literatos prestaram especial atenção a essa relação entre a importância da canção popular e seu contexto de superação da escola romântica. Comecemos por Adorno, que reconheceu a importância dessa relação ao apontar para o lugar da canção popular e folclórica em compositores centrais de sua época, como também para a falta de ligação entre esses nacionalistas e o dos românticos do século XIX.

[...] não se deveria computar impensadamente as radicais tendências de cunho folclórico do século XX, tal como são corporificadas, por exemplo, em importantes compositores como Bartók e Janáček, entre os desenvolvimentos posteriores das escolas nacionais do romantismo tardio. Apesar de procederem destas ultimas, voltaram-se justamente contra a manipulação, 
de modo análogo ao protesto dos povos subjugados contra o colonialismo. O jovem Bartók tem tanta coisa em comum com seu compatriota Liszt quanto sua música se opõe à cultura cigana de salão ornamentada com vistas às grandes cidades. Suas próprias pesquisas folclóricas dirigem-se polemicamente contra a música cigana fabricada nas cidades, um produto decadente do romantismo nacional. Temporariamente, o momento nacional transformou-se, uma vez mais, em força produtiva musical. $\mathrm{O}$ recurso ao idioma efetivamente não documentado e tampouco preparado pelo reificado sistema musical ocidental transcorreu paralelamente à revolta da nova música avançada contra a tonalidade e contra a rígida métrica que se submete a esta última (Adorno, pp. 314/15).

Essas questões postas por Adorno, próprias da música do século XX, nos ajudam a compreender passagens importantes das reflexões de Nietzsche sobre a possibilidade de uma nova linguagem musical que estivesse para além do romantismo, e que ele associou, nas obras tardias, à arte dionisíaca. Nesse sentido, o ponto principal do argumento de Adorno é a dissociação entre os nacionalismos do século XX e aqueles do século anterior. Isso porque Nietzsche, superadas as influências que sofreu, e abandonando sua adesão ao programa romântico-musical, apenas em Carmen teria visto outra vez traços fecundos da canção popular. Portanto, haveria uma outra possibilidade de pensar uma nova linguagem musical, tendo como exemplo a força sonora dionisíaca, e que não fosse mais a da música romântica. Por isso, os nomes citados por Adorno são cruciais para entender essa nossa afirmação. A lista de nomes que integram essa alternativa à música romântica é extensa, mas esses dois hão de nos bastar. De fato, tanto o compositor tcheco Leoš Janáček quanto o húngaro Bela Bartók figuram entre os nomes mais importantes da música no século XX, cujas obras são marcadas com muita força pela presença da canção popular ou folclórica ${ }^{9}$.

9 David Schneider (2006) lembra-nos da singularidade invocada por Bartók 
Da perspectiva musical, essas obras que expressam uma tendência da renovação da linguagem musical podem nos ajudar a pensar as teses de Nietzsche sob outra perspectiva.

Não se trata, é certo, de estabelecer vínculos onde não há; antes é preciso considerar que boa parte das reflexões de Nietzsche sobre a música pode ser mais bem compreendida se ampliarmos o seu horizonte de interpretação, o que significa dizer que há um descompasso entre as questões postas pelo filósofo e o seu entorno musical. Sabemos que Nietzsche, em $O$ caso Wagner, não apenas reavalia sua visão sobre o compositor, como também vai partir de pressupostos bastante distintos daqueles de $O$ nascimento da tragédia a fim de expor seus argumentos. Assim, em vez de princípios metafísicos, históricos e musicológicos, vai, em síntese, lançar mão de uma fisiologia da arte para combater Wagner (NW/NW, No que faço objeções, KSA 6.418). Contudo, é possível pensar nas teses filosóficas iniciais desvencilhadas da obra wagneriana, sem ter de passar necessariamente pelo caminho da fisiologia. Como, em termos musicais, o foco musical nos dois momentos da obra de Nietzsche é Wagner, podemos, portanto, ampliar nosso campo de compreensão da música a partir das ideias de Nietzsche sem ter

diante de outros compositores de sua época, justamente por ele não identificar-se, tal como aponta Adorno, com a tradição nacionalista húngara. O compositor tinha claro que já ninguém, no início do Século XX, conseguia mais suportar o estilo romântico e que por isso era preciso provocar uma ruptura total com o século anterior. No caso de Bartók, essa ruptura se deu muito em função da adoção da linguagem da música popular e folclórica, o que confere o caráter inovador não apenas em termos musicais mais amplos, como também o torna um pioneiro nessa área em sua nação. Cabe destacar, todavia, que o livro de Schneider pretende pôr em discussão essa suposta falta de predecessores para a música de Bartók. No caso de Leoš Janáček, Zdeněk Skoumal (1999, p. 127) considera que a ligação do compositor com a canção folclórica [Folk-song] revela tanto a admiração dele por esse tipo de arte quanto a herança do século XIX. O amor genuíno que ele tinha pela música popular folclórica teria moldado sua arte e sua filosofia da existência, pois ele afirmava que na canção popular se encontra a pessoa inteira, o corpo, a alma e o ambiente. 
em Wagner esse percurso circular que o torna ponto de partida e de chegada.

Se pensarmos o conjunto de teses, questões e problemas com que Nietzsche expõe o dionisíaco em sua obra, considerando tanto seus escritos iniciais quanto os escritos a partir de 1886, e concatenar esse conjunto com as reflexões tardias sobre a música, podemos sair desse círculo wagneriano. Desde logo, o dionisíaco se revela como a linguagem cuja forma afigural foi capaz de renovar a relação entre sons e palavras, por meio da irrupção do ditirambo. Ainda que possa haver uma reconstrução erudita nessa compreensão do fenômeno dionisíaco (GT/NT 18, KSA 1.115), foi nela que Nietzsche construiu aquela "imagem de uma antiguidade ideal" para pensar uma alternativa à música moderna. Ao romper com Wagner e afastar de suas considerações sobre a canção popular dionisíaca o romantismo alemão, esse componente erudito só fez ampliar o alcance das teses do filósofo. Em outras palavras, a canção popular, tendo como modelo a música dionisíaca e livre do ideal romântico, abre uma outra possibilidade de pensar a música na filosofia nietzschiana. Em nosso entender, as teses iniciais podem nos fornecer elementos para arriscar uma interpretação segundo é possível compreender uma tendência musical posterior ao filósofo nos moldes do que ele pensava sobre a música dionisíaca, sobretudo em sua vertente popular e bárbaro-primitiva.

Não se trata, como dissemos, de afirmar que houve influência de Nietzsche sobre compositores que foram buscar na linguagem da canção folclórica e popular um modelo privilegiado com que renovaram a tradição da música ocidental. Os casos de Janáček e de Bartók nos mostram antes que o tipo de composição que é um traço característico de suas obras integra um pano de fundo artístico, filosófico e cultural cujos pressupostos podemos encontrar na relação que Nietzsche fez entre canção popular e a música dionisíaca. Assim como os compositores do início do século XX sentiram o esgotamento da linguagem musical romântica e buscaram na canção 
folclórica uma fonte de renovação, também Nietzsche, já nas suas obras tardias, percebeu a aporia em que se encontrava a música, polarizada entre o romantismo de Wagner e o de Brahms ${ }^{10}$. Deleuze considera, por exemplo, que o artista romântico abandona a ideia de universalidade em busca de uma territorialização. Apesar disso, ao típico artista romântico, ou seja, o alemão, falta o povo, diferente do que ocorre com os latinos e os eslavos, onde tudo passa pelo tema de um povo e pelas forças de um povo (Deleuze, 1997, p. 156). Nesse sentido, Deleuze conclui que Bartók pôde "apoiar-se nas canções populares ou de população, para fazer populações elas próprias sonoras, instrumentais e orquestrais" (p. 158).

Além de Adorno e Deleuze, o romancista tcheco Milan Kundera, em suas muitas páginas literárias dedicadas à música, nos lança nesse mesmo horizonte de relação entre canção popular, identidades cultuais e, mais ainda, de retorno do dionisíaco. Em seu romance $A$ brincadeira, o personagem Jaroslav faz um mergulho nessa ligação entre canção popular e identidade nacional que nos ajuda a compreender a questão desde uma perspectiva de quem está imerso no problema, uma vez que o enredo dá testemunho de um contexto histórico e político marcado pela necessidade da arte como afirmação de uma cultura e de uma região. Jaroslav aponta para o fato de que, nos séculos XVII e XVIII, o povo tcheco como que deixou de existir, e sua língua, expulsa dos grandes centros, sobreviveu porque se refugiou entre os iletrados. Essa cultura de resistência teria sido a base para o renascimento do país no século

10 Apesar de ser possível, como é nossa tese, projetar as reflexões musicais de Nietzsche no mesmo mosaico onde estão as motivações que levaram uma grande parte de compositores a adotar a canção popular e folclórica como parte da linguagem para suas composições, a primeira recepção das ideias do filósofo foi justamente a dos compositores do romantismo tardio, como bem aponta Zoltan Roman (1978), lembrando que Frederick Delius, Richard Strauss e Gustav Mahler compuseram obras baseadas em Assim falava Zaratustra. Por óbvio, é preciso separar o que é reflexão de Nietzsche sobre a música dos elementos por assim dizer poéticos de sua obra. Foram nestes últimos que se inspiraram os três compositores, e a relação deles com a obra nietzschiana não seria similar à de Wagner com a de Schopenhauer, isto é, aquela em que as considerações teóricas influenciariam a própria concepção musical. 
XIX, sendo as canções um fundamento importante desse processo. Contrariando a noção de que as canções populares daquela região derivavam da música erudita do barroco, o personagem afirma que elas eram cantadas em tons inconcebíveis para as orquestras europeias. Graças a uma outra complexidade harmônica que existia ali, Bartók teria criado o termo parlando para referir-se a essa tonalidade, e o sistema de notação europeu não estava apto a transcrever seu ritmo. Janáček, por sua vez, atribui essa complexidade às variações de humor dos cantores.

O personagem Jaroslav conclui que as canções e ritos populares são um túnel que traz de volta tudo aquilo que, na história, as guerras, as revoluções e a civilização destruíram. No fundo, toda essa canção popular se ampara noutras sonoridades, a do tetracórdio lídio, frígio ou dórico, e por isso traria de volta as Dionisíacas da Grécia Antiga.

A antiguidade! Isso me parecia inacreditável! No entanto, em seguida estudei na Universidade a história do pensamento musical. A estrutura de nossas mais antigas canções populares está, realmente, de acordo com a estrutura da música antiga. O tetracórdio lídio, frígio ou dórico. Concepção descendente da escala que tem como fundamental o tom alto, e não o inferior, o que sucederá apenas quando a música começar a desenvolver-se em termos harmônicos. Assim, nossas canções populares mais antigas pertenciam à mesma época do pensamento musical daquelas que eram cantadas na Grécia antiga. Elas nos conservam o tempo da antiguidade (Kundera, 1986, pp. 180/181).

Adorno e Deleuze, cada um à sua maneira, destacam a importância da canção popular e folclórica no contexto dos movimentos de afirmação das identidades dos respectivos povos de onde irrompe o canto folclórico; além disso, os dois afirmam, também, a singularidade da estética na qual se inserem os compositores que fizeram uso desses modos musicais, demarcando a diferença deles em relação ao nacionalismo dos românticos. Milan Kundera, por sua vez, além de reconhecer a importância da canção popular para identidade do povo tcheco desde o final do século XIX, encontra a 
raiz dessas canções na Grécia antiga. Há que se notar que os nomes dos compositores Bartók e Janáček aparecem como sendo os modelos de suas considerações.

É certo que Nietzsche, no "Ensaio de autocrítica", ao perguntar onde poderia ouvir outra vez uma música que não fosse romântica e alemã, mas dionisíaca, não retoma suas reflexões musicais sobre o dionisíaco de seus primeiros escritos, tampouco considera a ópera Carmen como resposta à questão. A despeito disso, o que procuramos neste artigo foi mostrar que é possível dissociar as teses históricas e musicológicas sobre o fenômeno da música dionisíaca daquelas influências que, segundo o próprio filósofo, haviam estragado o que ele tinha a dizer sobre os gregos. Isso nos permite vislumbrar um alcance bem maior para as questões que Nietzsche colocou sobre a música em seu tempo. Nesse sentido, se a canção popular entre os gregos, tal como defende em $\boldsymbol{O}$ nascimento $\boldsymbol{d a}$ tragédia, representou uma linguagem sonora tão importante que deu um novo ímpeto para a poesia lírica e foi de fundamental importância para fazer surgir a tragédia, ao desvincular essa dimensão de suas teses sobre a música grega antiga das concepções estéticas modernas, Nietzsche nos oferece um conjunto de reflexões sobre a música que nos permite pensar boa parte da música mais importante do século XX em sintonia com a relação que o filósofo estabeleceu entre a canção popular e o dionisíaco.

\begin{abstract}
The article aims at analyzing the relationship between popular song and Dionysian music taking into account Nietzsche's metaphysical and musicological considerations in The birth of tragedy. It seeks to show Nietzsche's reasons for the importance of popular song to the development of the Greek arts, which culminate in tragedy. Indicating how the union between sound and words takes a decisive role on this development, it hopes to exhibit Nietzsche's theories about the subject within his first writings, in order to maintain, afterwards, that his latter selfcritique allows us to amplify his musical ideas and thus to think about the musical context in 20th Century.
\end{abstract}

Keywords: popular song - folk song - music - Dionysian - art 


\section{Referências bibliográficas}

ADORNO, Theodor. Introdução à sociologia da música. Tradução de Fernando Barros. São Paulo: Ed. Unesp, 2009.

CORBIER, Christophe. "Harmonia e música dionisíaca: do drama musical grego ao Nascimento da tragédia”. In. Cadernos Nietzsche, São Paulo, N. 34, Vol. 1, 2004, pp. 61-98.

DUFOUR, Eric. "La physiologie de la musique de Nietzsche". In: Nietzsche Studien (30). Berlim: Walter de Gruyter, 2001, pp. 222-245.

HEGEL, G. W. F. Estética (Vol. III). Tradução de Marco Aurélio Werle e Oliver Tolle. São Paulo: Edusp, 2014.

KUNDERA, Milan. A brincadeira. Tradução de Teresa Bulhões e Anna Lucia Moojen. Rio de Janeiro: Nova Fronteira, 1986.

NIETZSCHE, Friedrich. Sämtliche Werke. Kritische Studienausgabe, Berlim: Walter de Gruyter \& Co., [1967/1978- estas são datas da KGW]. 15 vols. (Organizada por Giorgio Colli e Mazzino Montinari).

. O caso Wagner. Tradução de Paulo César de Souza. São Paulo: Cia das letras, 1999.

ROMAN, Zoltan. "Nietzsche via Mahler, Deliüs and Strauss: a new look at some fin-de-siècle "philosophical music"”. In. Nietzsche Studien (16), 1978. Berlim:Walter de Gruyter \& CO., pp. 292-311.

SCHNEIDER, David. Bartók, Hungary, and the renewal of tradition. Case studies the intersection of modernity and nationality. Berkeley: University California Press, 2006.

SILK, S.; STERN, J. P. Nietzsche on tragedy. Cambridge: Cambridge University Press, 1983.

SKOUMAL, Zdeněk. "Leoš Janáček's Folk settings and the Vixen". In: WINGFIELD, Paul (Ed). Janáček Studies. Nova Iorque: Cambridge University Press, 1999.

WAGNER, Richard. Oper und drama. Leipzig: Weber, 1852.

Artigo recebido para publicação em 14/09/2016.

Artigo aceito para publicação em 30/10/2016. 